\title{
Music Criticism in Nineteenth-Century England: How Did it Become a Profession?
}

\author{
Paul Watt / paul.watt@monash.edu \\ Monash University, Melbourne, AUS
}

\begin{abstract}
Of the two-dozen professions that emerged in nineteenth-century Britain, such as medicine, the law and the public service, music criticism was a late developer. This paper examines the social, economic and intellectual factors that led to the establishment of music criticism as a profession and the ways institutions such as the Musical Association and the Musical Times contributed to this process of professionalization. I argue that the path to making music criticism a creditable profession was neither a top-down nor bottom-up approach; rather it was a ubiquitous movement driven by newspapers readers, editors and composers.
\end{abstract}

\section{Keywords}

critic, journalism, ethics, professionalization, literary style 
In 1857 a writer called H. Byerley Thomson published a book called The Choice of Profession: A Concise Account and Comparative Review of the English Professions. ${ }^{1}$ At over 400 pages the book was hardly concise but it was nonetheless a professional guide for aspiring clerics, lawyers, medical doctors, civil servants, painters, sculptors, architects, engineers, teachers, actors, writers, military personnel and musicians. Each chapter detailed particular skills required to enter the professions, such as taking examinations, and discussed the role that regulatory and professional bodies played in supporting the aspiring professional. In the chapter on the music profession a potted history of degrees in music was provided along with a list of the rules and regulations of the Royal Academy of Music. At the end of the article the author provided a taxonomy of the music profession, arranged in three sections:

I. In the first division will stand:

1. The composer.

2. The theorist, or teacher of acoustics.

3. The teacher of harmony, or counterpoint, \&c.

II. In the second will be included-

1. The organist and pianist. Public performer and teacher, for they are generally combined.

2. The orchestral instrumentalist.

3. The vocalist.

III. In the third division will be classed:

1. The writers, engaged by the press, whose province it is to attend concerts, review musical works, \&c. \&c.

2. The lecturer on the science and practice of music.

The writer on music is delegated to the last section, strongly suggesting that the music journalist and critic were the least important.

This article explains how the English music critic would, by the end of the nineteenth century, enjoy a much higher reputation than in the late 1850 s when Thomson's book was written and I will ask: Why was this so? In reply, there are three answers. First, the public demanded better music criticism and they advocated strongly for a more professional approach to writing about music. Second, attempts were made to educate critics to facilitate better writing style. Third, plans were articulated to regulate the office of the critic through establishing principles for criticism.

1 THOMSON, H. Byerley. The Choice of a Profession: A Concise Account and Comparative Review of the English Professions. London: Chapman and Hall, 1857. For other literature on the professions in nineteenth-century England see CARR-SAUNDERS, A.M. and WILSON, P.A. The Professions. Oxford: Clarendon Press, 1933; CORFIELD Penelope, J. Power and the Professions in Britain 1700-1850. London and New York: Routledge, 1995; and READER, W.J. Professional Men: The Rise of the Professional Classes in Nineteenth-Century England. London: Weidenfeld and Nicolson, 1996. 


\section{The public's desire for better criticism}

Quality criticism was seen as a civil and social good. As early as 1824, for example, an article in the Edinburgh Review outlined the duty of critics to improve their readers lives: to "correct their errors; to expose their prejudices; to refute opinions which are generated only by partial interest [and] ... to increase the sum of happiness, lessen the sum of misery". 2

More than seventy-five years later a book on English journalism by Leslie Stephen, Newspaper Reporting in Olden Time and Today, echoed these sentiments. Stephen praised the rapid growth of the English newspaper press as enabling a "nobler social condition" and for "lifting England out of the darkness of prejudice and ignorance". "Yet some writers believed that journalism also needed to be ethical. Writing in the Examiner in 1873, Stephen saw the journalist as an agent of "social morality" who should exercise ethical judgement. ${ }^{4}$ The inability of a critic to keep his judgement in check was a long-held problem: in the words of the music historian John Hawkins as far back as 1776, the problem of opinion made the critic a mere "capricious arbiter". ${ }^{5}$

One way to emancipate critics from darkness and prejudice was to train or educate them.

\section{Education}

A slew of publications from the late 1860s to the 1910s helped guide the aspiring critic to a career. These books and articles covered topics such as what a potential critic should read, the style in which critics should write, and practical advice on how to best execute their job when employed as a staff writer or a freelance journalist. On occasion, female journalists were given advice on how to maintain a career in an era of severe competition dominated by men. Music critics were also offered counsel on how to break into this specialized profession.

Self-help books were not the only sources from which critics could learn their craft. Dozens of newspapers published articles on topics ranging from writing style to ethics; these articles were complementary sources to the self-help primers. However, there is little evidence that music critics of this era consulted such literature or were greatly affected by it: the careers of Herman Klein (1856-1934), J.A. Fuller Maitland (1856-1936) and Ernest Newman (1868-1969) shows that forging a career in musical criticism was not about what you knew, as much as who you knew. In some cases critics landed their jobs by simply being in the right place at the right time.

\footnotetext{
2 UNSIGNED, Periodical literature. Edinburgh Review, January 1824, p. 206-246; 207.

3 PENDLETON, JOHN. Newspaper Reporting in Olden Time and Today. London: Elliot Stock, 1899, p. v-vi.

4 STEPHEN, Leslie. Of the aspects of criticism. Examiner, 13 December 1873, p. 1234-1235; 1234.

5 HAWKINS, John. A General History of Music from the Earliest Ages to the Present (4 vols.). London: Payne and Son, 1779 [1776]), p. xii-xvii.
} 
The first step in getting a job as a journalist or critic was to know the attributes that prospective employers were seeking. In the 1860s, according to a writer Thomas Allen Reed, most critics lacked general knowledge, and this was the most essential skill: "Not one in twenty, even among those employed in first-class journals, has had the benefit of a university training; and comparatively few can boast of a good classical education" ${ }^{6}$ In Reed's view a classical education meant knowledge of Latin (in order to understand quotations), French (because it is the "most useful modern language"); and the Greek alphabet (to comprehend scientific terms). ${ }^{7}$ Furthermore, Reed suggested that knowledge of history was necessary in order to understand speeches-in addition to keeping up to date with current affairs-and to cultivate "a little legal knowledge" and a "good physical constitution". ${ }^{8}$ Like many other writers of such books, Reed also listed shorthand as a necessary skill for the aspiring writer and provided a list of essential reading for the beginner (see Tab. 1). ${ }^{9}$

\begin{tabular}{l}
\hline Webster's Dictionary \\
Latin, French, Greek dictionaries \\
Chambers Encyclopedia or Encyclopedia Britannica \\
Haydn's History of Dates \\
Roget's Thesaurus \\
\hline Bohns' Dictionary of Classical Quotations \\
Cruden's Concordance \\
\hline Imperial Gazetteer \\
\hline Imperial Biographical Dictionary or any reference work that has a biographical section \\
\hline
\end{tabular}

Tab. 1 Thomas Allen Reed's list of books required by a beginning reporter Source: ALLEN REED, Thomas. The Reporter's Guide. London: Pitman, 1869, p. 120.

The need for wide reading in history and literature was at the forefront in A. Arthur Reade's Literary Success of $1885 .{ }^{10}$ He was also concerned with cultivating ethical criticism

6 ALLEN REED, Thomas, The Reporter's Guide. London: Pitman, 1869, p. 10.

7 Ibid., p. 12.

8 REED, p. 14. Another writer, Percy Russell, supposed that critics should be so robust as to be 'able to go without sleep'. RUSSELL, Percy. The Literary Manual: A Complete Guide to Authorship. London: London Literary Society, 1886, p. 177.

9 REED, op. cit., p. 14.

10 READE, A. Arthur. A Literary Success: Being a Guide to Practical Journalism. 2nd ed. London: Wyman \& Sons, 1885. 
and provided a list of eleven principles of ethical conduct (based on work by Mr. Philip Gilbert Hamerton, an art critic):

1. To utter unpopular truth.

2. To instruct the public in the theoretical knowledge of art.

3. To defend living artists against the malice of the ignorant.

4. To prevent false living artists from acquiring an influence injurious to the general interests of art.

5. To exalt the fame of dead artists whose example may be beneficial.

6. To weaken the fame of dead artists whose names have an injurious degree of authority.

7. To speak always with absolute sincerity.

8. To give open expression to vicissitudes of opinion, not fearing the imputation of inconsistency.

9. To make himself as thoroughly informed as his time and opportunities will allow about everything considering the Fine Arts, whether directly or indirectly.

10. To enlarge his own powers of sympathy.

11. To resist the formation of prejudice. ${ }^{11}$

Many other writers of the late nineteenth century gave similar advice to emerging writers. W.T. Stead in A Journalist on Journalism (1892) emphasized the need to embrace technology. In addition to learning to read French and German, which was recommended by many writers, Stead advocated developing skills in legible writing, shorthand and typewriting. ${ }^{12}$

There was little disagreement amongst authors of primers and articles about the need for a critic to write well. A. Arthur Reade had much to say in his Literary Success: A Guide to Practical Journalism in 1885. He coined a term, "reporter's English", and it was not meant kindly: it was a pejorative term and referred to the "vitiated and pretentious style which passes current in our newspapers". ${ }^{13}$ Reade then proposed four rules for good reporter's English: 1. Be brief; 2. Use short words; 3. Use plain English; 4. Be accurate. ${ }^{14}$

Other writers gave much more specific instruction for style, as W. T. Stead did in his book A Journalist on Journalism of 1892:

Avoid long involved sentences in which the reader's mind gets tangled. As an exercise, after you have written an article, imagine that you had to telegraph it to Australia at a pound a word-to be paid out of your own pocket. The process of condensation from the diffuse essay style to the crisp, condensed, laconic, nervous style of the telegram will probably make your meaning stand out much more clearly. ${ }^{15}$

11 Ibid., p. 88.

12 Stead, op.cit., p. 23-24.

13 Reade, op. cit., p 24. Here, Reader was quoting, from an unnamed source, the Dean of Canterbury, editor of the Contemporary Review.

14 Ibid., p. 24.

15 Stead, op. cit., p. 23. 


\section{Principles}

Like their literary counterparts, music critics-as well as composers-were concerned about a lack of ethics in criticism and the need for principles to regulate their profession. The first attempt to treat the subject in detail was by the pianist and composer Charles Kensington Salaman. In a speech to the Musical Association in late 1875, Salaman outlined the need for musical criticism to be governed by a set of principles (or standards, as he termed them). An appropriate course of training needed to make the office of music critic an honourable profession'. ${ }^{16}$

Salaman also advocated that critics should cultivate a logical mind. ${ }^{17} \mathrm{~A}$ critic, he wrote, should also value novelty, be able to distinguish between a genius and a pioneer, and should avoid conflicts of interests with publishers and friends.

The composer John Stainer was another advocate for principles of musical criticism and delivered a speech on the subject (just as Salaman had done five years earlier) to the Musical Association in $1880 .{ }^{18}$ Stainer observed that "Musical criticism at the present moment is oscillating dangerously between the two extremes of dogmatic conventionalism and unblushing nihilism. I think it is the duty of all of us to try and steady it". ${ }^{19}$ Given so many ill-considered judgements from critics, Stainer believed they had become "unjust judges and false prophets". ${ }^{20}$ He viewed the reporting of personal opinion without the support of "intellectual and emotional training" as a major cause for concern. ${ }^{21}$

In the same year Stainer's article was published, 1893, Frederick J. Crowest painted a similarly bleak picture of contemporary music criticism in his book, Phases of Musical England, suggesting that criticism was in such a dire position that it constituted a national crisis:

The present condition of Musical Criticism in England cannot be said to be remarkable either for its quantity or genuine quality. At the most, our fund of criticism is only represented by an occasional notice in one or more of the daily journals, and by a few class papers ... For instance, what good is served by the untutored splutterings of the anonymous writers in our weekly and biweekly prints-writers who, under the garb of some high-flown nom-de-plume, regale their readers with flippant notes upon a subject of which such writers know comparatively nothing. Why should the public lend itself to such a prostitution of good ink and paper? Scraps of personal gossip and bits of scandal and slander cannot be called criticism, malgré newspaper proprietors permit their columns to be lowered with the insertion of such rubbish. ${ }^{22}$

16 SALAMAN, Charles Kensington. On musical criticism. Proceedings of the Musical Association, second session, 1875-1876, p. 1-15.

17 Ibid., 'On musical criticism', p. 3.

18 STAINER, John. The principles of musical criticism. Proceedings of the Royal Musical Association, seventh session, 1880-1, p. 35-52.

19 Ibid., p. 37.

20 Ibid., p. 42.

21 Ibid.

22 CROWEST, Frederick J. Phases of Musical England. London: Remington and Co., 1881, p. 9-10. 
W. H. Hadow followed suit in his criticism of contemporary music criticism in Studies in Modern Music (1893). According to Hadow, there were too many ideas and opinions expressed in musical literature generally (but in criticism in particular) that lacked the voice of authority. In part 1 of the article Hadow bemoaned that the public accepted any old opinion, not because they were ignorant, but because they were "browbeaten out of all reliance on [their] own judgment". ${ }^{23}$ For Hadow, music critics were far too heavy-handed and cavalier. To counter musical criticism of this type, he identified three grounds on which principles or authority could be established: 1. writing about music with "clearness and certainty"; 2. finding suitable words to express an art form; and 3. using parameters, such as harmony and counterpoint, to rationally and objectively interpret music.

Hadow concluded this long chapter accusing his contemporaries of "dogmatic denunciation". ${ }^{24}$ He even went so far as to suggest that the public would be better off without critics: he felt they could make up their own minds about musically worthy.

\section{Schools for Music Critics}

In 1885 the music critic Joseph Bennett proposed a Royal Academy of Musical Criticism to provide training in writing and the cultivation of musical knowledge. ${ }^{25}$ This plan came to nothing.

Similarly, a Royal College of Critics was proposed in 1894 but it was feared that given to local indifference-and "much howling"-such a scheme would not be possible until the end of the millennium. ${ }^{26}$ The proposed College was the subject of a satirical article in the Magazine of Music in February 1894. The un-named author clearly thought the establishment of such an institution a ridiculous idea. The article had an air of condescension to the idea that a music critic should be a professional and was contemptuous of the sorts of questions that might be asked in an examination paper to confer this professional status. The contempt for the proposed college is obvious in the following questions, which were to form part of the fictional exam paper:

1. State your reasons for believing musical criticism to be a moral occupation or the reverse.

2. Give briefly what you consider the necessary qualifications for a critic.

3. What is meant by the critic's "duty to the public"?

4. Who was the first musical critic?

5. Who was the second?

6. Give dates of the birth of Mozart, Beethoven, Wagner, and John Smith.

23 HADOW, W.H. Studies in Modern Music. London: Seeley, 1893, p. 4.

24 Ibid., p. 60.

25 BENNETT, Joseph. Types of musical character III: The musical critic, Lute: A Monthly Journal of Musical News, 2 November 1885, p. 241-243.

26 UNSIGNED. The Royal College of Critics. Magazine of Music, February 1894, p. 43. This article was a sarcastic take on proposals to regulate criticism through training. 
7. Show how the conquests of Alexander affected Samuel Sebastian Wesley in composing his great anthems.

8. What is the connection between Noah's ark and consecutive fifths?

9. Show how the critic may be biased - first, by what he has just had for dinner; second, by the fact that the singer he is criticising is $(a)$ his wife; $(b)$ his mother-in-law; $(c)$ a friend he dislikes; $(d)$ a friend he likes; $(e)$ a mortal enemy; $(f)$ his sweetheart; $(g)$ himself.

Ernest Newman outlined a further plan for a school in the Musical Times in January 1911. ${ }^{27}$ This article was a response to a recent lecture by M.D. Calvocoressi at the École des Hautes Études in Paris on method in criticism. Newman held Calvocoressi in high regard and supported his idea for method and was enthusiastic for a similar course in England:

Will anyone who has practiced musical criticism for any length of time deny that a young man with a real critical gift would be all the better for a few years' coaching by someone who had had a wide experience of criticism and had thought seriously about its problems?28

Furthermore, Newman thought it greatly advantageous for a young critic to be schooled in the principles of criticism (though what exactly these principles were, Newman did not elaborate) and ends the article by suggesting a significant need for such an undertaking:

And until the critic can go to school as the composer and performer can, and profit, like them, by what previous workers in the same field have learned, most criticism will remain the haphazard and dogmatic and contradictory thing it is at present. ${ }^{29}$

Overcoming haphazard, dogmatic and contradictory criticism were the three concerns of the public, editors, publishers and the more professional music critics in nineteenthcentury England. Behind the scenes, though, much else was happening. For example, after 1860 anonymous criticism, which allowed critics to be spiteful, nasty, wrong and unaccountable, was on the decline: by 1910 most newspapers and journals on all subjects were no longer printing unsigned articles. Other developments in criticism in included the rise of the essay: a genre of writing encompassing biography, history, aesthetics and / or psychology, often in a comparative vein. Increasingly, the divide between reporting, journalism, criticism and scholarship blurred. Only authority and expert opinion mattered in the periodical press: writing was required to be professional and there was no room now for opinions or mere impressions. And, of course, underpinning the rise of the professional writer in late nineteenth-century Britain was the establishment of the

27 NEWMAN Ernest. A school for musical critics, Musical Times, January 1911, 16-17.

28 Ibid., p. 16.

29 Ibid., p. 17. 
Society of Authors and the National Association of Journalists (both founded in 1884), the Publishers Association (founded 1896) and the National Union of Journalists (founded 1907)..$^{30}$

\section{Conclusion}

By the end of the nineteenth century the leading English music critics were no mere reporters, in their spare time, of second-rate concerts. To be sure concert reviewing was part of their brief but critics wrote across a greater variety of genres. They wrote essays on biography, history and literature; wrote and translated librettos and books and wrote book reviews as well as writing their own books. The more successful critics had their works reproduced in anthologies. Alongside their literary counterparts they were selfmade women and men or had been mentored by experts. Most music critics could read at least one foreign language and for the most part there was serious engagement with the need to regulate and reform music criticism through establishing principles. Various attempts to set up colleges for music critics failed to materialize but this did not stymie attempts to raise the bar in a profession that in the 1850s was suffering from bad PR. By the 1890s the music critic was a professional. He may not have enjoyed full-time work as a critic or have his own by-line or belong to the Institute of journalists but he was generally held in higher regard than the previous generations of critics and could hold his own intellectually on the world stage.

\section{Bibliography}

ALLEN REED, Thomas, The Reporter's Guide. London: Pitman, 1869.

BENNETT, Joseph. Types of musical character III: The musical critic, Lute: A Monthly Journal of Musical News, 2 November 1885, p. 241-243.

BUNDOCK, Clement J. The National Union of Journalists: A Jubilee History, 1907-1957. London:

National Union of Journalists, 1957 and GOPSILL, Tim and Greg NEALE, Greg, Journalists: 100 Years of the NUJ. London: Profile Books, 2007.

CARR-SAUNDERS, A. M. and WILSON, P. A. The Professions. Oxford: Clarendon Press, 1933.

CORFIELD Penelope, J. Power and the Professions in Britain 1700-1850. London and New York:

Routledge, 1995.

30 On the National Association (later Institute) of Journalists, which was established to promote and preserve the status, social standing and well-being of its members, see HAMPTON, Mark. Journalists and the "professional ideal" in Britain: The Institute of Journalists, 1884-1907, Historical Research 72/178 (June 1999), 183-201. A National Union of Journalists was founded in 1907 to protect wages and conditions and its history can be found in MANSFIELD F. J. "Gentleman, The Press!": Chronicles of a Crusade [Official History of the National Union of Journalists] London: W. H. Allen \& Co. Ltd, 1943; BUNDOCK, Clement J. The National Union of Journalists: A Jubilee History, 1907-1957. London: National Union of Journalists, 1957 and GOPSILL, Tim and Greg NEALE, Greg, Journalists: 100 Years of the NUJ. London: Profile Books, 2007. 
CROWEST, Frederick J. Phases of Musical England. London: Remington and Co., 1881.

HADOW, W. H. Studies in Modern Music. London: Seeley, 1893.

HAMPTON, Mark. Journalists and the "professional ideal" in Britain: The Institute of Journalists, 1884-1907, Historical Research 72/178 (June 1999), 183-201.

HAWKINS, John. A General History of Music from the Earliest Ages to the Present (4 vols.). London: Payne and Son, 1779 [1776]).

MANSFIELD F. J. "Gentleman, The Press!": Chronicles of a Crusade [Official History of the National Union of Journalists] London: W. H. Allen \& Co. Ltd, 1943.

NEWMAN Ernest. A school for musical critics, Musical Times, January 1911, p. 16-17.

PENDLETON, JOHN. Newspaper Reporting in Olden Time and Today. London: Elliot Stock, 1899.

READE, A. Arthur. A Literary Success: Being a Guide to Practical Journalism 2nd edn. London: Wyman \& Sons, 1885.

READER, W. J. Professional Men: The Rise of the Professional Classes in Nineteenth-Century England. London: Weidenfeld and Nicolson, 1996.

RUSSELL, Percy. The Literary Manual: A Complete Guide to Authorship. London: London Literary Society, 1886.

SALAMAN, Charles Kensington. On musical criticism. Proceedings of the Musical Association, second session, 1875-1876.

STAINER, John. The principles of musical criticism. Proceedings of the Royal Musical Association, seventh session, 1880-1, p. 35-52.

STEPHEN, Leslie. Of the aspects of criticism. Examiner, 13 December 1873, p. 1234-1235.

THOMSON, H. Byerley. The Choice of a Profession: A Concise Account and Comparative Review of the English Professions. London: Chapman and Hall, 1857.

UNSIGNED. Periodical literature. Edinburgh Review, January 1824, p. 206-246.

UNSIGNED. The Royal College of Critics. Magazine of Music, February 1894, p. 43. 